\title{
WEADZTWO TERYTORIALNE GMINY. OD IDEI DO MITU
}

Mój jest ten kawałek podtogi Nie mówcie mi więc, co mam robić*.

\section{WSTĘP}

W roku 2020 mija trzydzieści lat funkcjonowania samorządu gminnego, co skłania do szeregu refleksji nad jego ocena. W jakim stopniu zrealizowane zostały pierwotne zamierzenie i oczekiwania, które formułowano w okresie poprzedzającym restytucję samorządu terytorialnego, jak również w trakcie prac nad projektami ustaw w roku 1990? Inicjatorzy tych prac głosili wówczas wiele haseł zachęcających do poparcia tej kolejnej w historii powojennej transformacji ustrojowej, tym razem przywracającej Polskę do demokratycznej Europy. Jej podstawa miała być samodzielna wspólnota mieszkańców gmin, które - mimo utrzymania tej samej nazwy jednostki podziału terytorialnego - miały zyskiwać osobowość prawna, a w jej ramach prawo decydowania o sprawach lokalnych przyznanych przez ustawy do ich właściwości.

\section{ROLA PIERWIASTKA TERYTORIALNEGO W POJMOWANIU GMINY}

U źródeł wszelkich koncepcji współczesnego samorządu terytorialnego, a zatem pod koniec XVIII w. pojawiały się równolegle dwa substraty: osobowy, czyli wspólnota ludzi, i materialny, czyli przestrzeń, w której wspólnota ta powstawała. Były one nierozerwalne, a zarazem wzajemnie uzależniające się. Dla przedstawicieli teorii naturalnej samorządu proces wyodrębnienia terytorium z przestrzeni był równie naturalny, jak proces wytworzenia się więzi łączacej osoby zamieszkujące je. Dochodziło do niego w wyniku osadnictwa ludzi w toku postępującej cywilizacji. Ludzie wybierali miejsce zamieszkania z uwagi na jego warunki bytowy, a dopiero w późniejszym czasie z osad tych powstawały większe struktury terytorialne, aż do poziomu państwa. Nawet

\footnotetext{
* Motto to fragment utworu zespołu Mr. Zoob, do którego słowa napisał Waldemar Miszczor.
} 
jeśli w późniejszym okresie tworzenie osad było wynikiem świadomego działania sprawujących władzę $\mathrm{w}$ tych państwach, to nie zmieniało to faktu, że wspólne zamieszkiwanie takiej osady musiało doprowadzić do wspólnoty interesów, a tym samym zorganizowania ich realizacji przez odpowiedni system lokalnej władzy.

Toteż w podejmowanych przez przedstawicieli kolejnych teorii samorządu próbach jego zdefiniowania, jeśli samo terytorium nie pojawiało się wprost jako wyróżnik gminy ${ }^{1}$, to jego znaczenie wynikało z treści definicyjnej w sposób logiczny, jak choćby wówczas, gdy zdaniem Georga Jellinka normy prawa komunalnego wynikaja z sąsiedztwa, a przecież ono wiązało się z trwałym zamieszkiwaniem w danym miejscu ${ }^{2}$. Nawet w projektach Heinricha Karola von Steina dostrzec można - korzystając z nowego odczytania pism twórcy pruskiej ordynacji miejskiej dokonanego przez Irenę Lipowicz ${ }^{3}$ - pierwiastek terytorialny, skoro swoja koncepcje honorowego uczestnictwa w organach pruskiego miasta wiąał on z lokalnymi elitami - doświadczonymi kupcami i rzemieślnikami, którzy z racji wieku przechodzili „w stan spoczynku” i mogli poświęcić się sprawom publicznym, a co najważniejsze - byli posesjonatami w odróżnieniu od znajdujących się wyłącznie pod pieczą samorządu, nieposiadających żadnej własności nieruchomości na terenie gminy i tym samym pozbawionych prawa wyborczego, pozostałych mieszkańców. Stąd już tylko krok do określenia samorządu terytorialnego jako terytorialnej korporacji publiczno-prawnej4, w której - jak charakteryzował ją Tadeusz Bigo - „terytorjum (Gebiet) jest istotną rzeczą dlatego, ponieważ gmina [...] wykonuje podobnie jak państwo zwierzchnictwo terytorjalne (Gebietshoheit). [...] Inne związki (Genossenschaften) działają wprawdzie zawsze w granicach pewnego obszaru, ale nie panują (herrschen) na nim tak, jak gmina"5. Jak podkreślał, w konsekwencji jedną z cech różniących korporację terytorialną od korporacji nieterytorialnych (inaczej osobowych) jest przymusowy charakter udziału w nich jej członków, wynikający z samego tylko zamieszkiwania na danym terytorium ${ }^{6}$.

Jak współcześnie podkreśla się w doktrynie, członkostwo we wspólnocie mieszkańców, w odróżnieniu od samorządów zawodowych czy gospodarczych, nie powstaje w wyniku oświadczenia woli przyjmującego określoną formę. Zarazem także członkostwo to nie ustaje w wyniku oświadczenia woli ani ze strony wspólnoty, ani ze strony jej członka. W odróżnieniu od korporacji osobowych, które mogą odmówić przyjęcia, ale mogą też pozbawić członkostwa ${ }^{7}$, gmina nie

1 Bethelémy (1920: 192): „La commune est l’association des habitants d’une agglomération en vue de s'administratrer eux même, de se défender, de pourvoir à la satisfaction des bésoins matériels et moraux que fait naitre le voisinage”.

2 Jellinek (1920: 642): „Diese Gebietskörperschaften ruhen auf den nachbarlichen Gemeininterssen”.

3 Lipowicz (2019): 36-37, 39.

${ }^{4}$ Relację o powstaniu i ewolucji poglądów na terytorialny charakter korporacji publiczno-prawnej zob. Blieback (1976): 375-451; Kirste (2017): 62-154.

${ }^{5}$ Bigo (1928): 172-173. (Pisownia oryginalna).

6 Bigo (1928): 76-77.

${ }^{7}$ Jedynie dla przykładu zob. art. 6 i 7 ustawy z 2 grudnia 2009 r. o izbach lekarskich (Dz. U. 2019, poz. 965). 
przyjmuje do wspólnoty, ale nie może z niej nikogo wykluczyć. Członkostwo powstaje i ustaje jedynie w wyniku stanu faktycznego zamieszkania lub zaprzestania zamieszkania na terytorium gminy, przy czym w pierwszym przypadku nie ma znaczenia, czy osoba przybywa na terytorium gminy, czy też rodzi się na nim i tam pozostaje, w drugim przypadku nie ma znaczenia, czy osoba zmienia miejsce zamieszkania poza terytorium gminy, czy zaprzestanie zamieszkania następuje w wyniku śmierci tej osoby ${ }^{8}$. Zarazem Piotr Lisowski zwraca uwagę na różnicę między członkostwem we wspólnocie z racji samego tylko zamieszkiwania a uczestnictwem w sprawowaniu władzy (mówi o nim art. 11 ustawy o samorządzie gminnym), które jest uwarunkowane posiadaniem prawa wyborczego w rozumieniu przepisów prawa ${ }^{9}$.

Podsumowując, stwierdzić można, że terytorium stało się czynnikiem wyróżnienia kategorii pojęciowej terytorialnej korporacji publicznoprawnej, podstawa jej materialnego istnienia jako konkretnej gminy ${ }^{10}$, miejscem zamieszkania warunkującym członkostwo w korporacji, obszarem sprawowania władztwa przez gminę, a dokładniej jej organy, a zarazem miejscem wyznaczenia ich właściwości. Na tych założeniach oparte zostały definicje: konstytucyjna jednostki samorządu terytorialnego oraz ustawowe gminy, powiatu i województwa, w każdej z nich bowiem terytorium jest podstawą do powstania odpowiedniej wspólnoty samorządowej.

\section{WŁADZTWO TERYTORIALNE: POJĘCIE I PRZEJAWY}

Przywołane już koncepcje doktrynalne samorządu terytorialnego akcentowały substrat terytorialny gminy nie tylko jako samą przestrzeń do powstania wspólnoty jej mieszkańców, ale też jako obszar właściwości jej działania. W myśl założeń teoretycznych oraz przyjętych rozwiązań prawnych gmina samodzielnie wykonuje powierzone jej zadania, co wyznacza jej pozycję ustrojową w państwie, jako niezależność od innych organów ${ }^{11}$, w tym zwłaszcza organów administracji rządowej, sprawujących nadzór nad tą działalnością. Samodzielność ta opiera się na czterech podstawach: osobowości prawnej, władztwie, nadzorze sprawowanym nad działalnościa samorządową i sądowej ochronie samodzielności ${ }^{12}$, pozostających w ścisłym powiązaniu ze sobą i wzajemnym uwarunkowaniu, osobowość publiczno-

8 Oczywiście poza rozważaniem pozostaje czasowy pobyt na terytorium gminy, który nie spełnia warunku z art. 25 k.c.

9 Zob. art. 10 i 11 ustawy z 5 stycznia 2011 r. - Kodeks wyborczy (Dz. U. 2020, poz. 1319). Lisowski (2013): 212-259.

10 Jak pisał w połowie XIX w. Szymański (1849: 386) dla bytu gminy francuskiej istotne jest to przede wszystkim to, że: „Granice nie mogą być zmieniane bez upoważnienia władzy prawodawczej".

11 Fleiner (1922: 98) upatrywał w terytorialnym wyodrębnieniu gminy ograniczenie władzy państwa „Die Selbstverwaltung ist die Schranke gegen Omnipotenz des Staates”.

12 Szersze uzasadnienie tej konstrukcji pojęcia samodzielności jednostki samorządu Korczak (2012): 212-239. 
prawna wyposaża bowiem jednostkę samorządu terytorialnego we władztwo, sprawowane pod nadzorem państwowym, ale zarazem sądownie chronione przed jego ograniczeniem przez nieuprawniona ingerencję organów nadzoru. Wyeksponowanie władztwa spośród wszystkich podstaw samodzielności ma swoje uzasadnienie historyczne i doktrynalne, jak bowiem podkreśla się w licznych publikacjach, to prawne (ustawowe) wyposażenie gminy we władztwo (nazywane często w XIX w. zwierzchnościa) było historycznym momentem, gdy gmina zaczęła przekształcać się w terytorialną korporację publicznoprawną w miejsce dawnej przedsamorządowej gminy traktowanej co najwyżej w sferze prawa cywilnego ${ }^{13}$.

Teoria władztwa gminy ukształtowana w dziewiętnastowiecznej doktrynie niemieckiej od samego niemal początku ukształtowana była nie tyle na ,ściśle ujmowane władztwo, rozumiane jako kompetencja jednostronnego, wiążącego określania sytuacji prawnej adresatów działań gminy”, co raczej jako „właściwość gminy do regulacji określonych spraw, odniesiona przede wszystkim do samej gminy, do jej własnych spraw ustrojowych"14, rozciagajacca się na wszystkie przejawy samodzielności gminy. Poparciem tej tezy jest choćby dyrektywa płynąca $\mathrm{z}$ art. 3 EKSL do takiego ukształtowania w prawie krajowym warunków funkcjonowania społeczności lokalnych, aby były one zdolne do kierowania i zarządzania zasadniczą częścią spraw publicznych na ich własną odpowiedzialność i w interesie jej mieszkańców. Nie istnieje zamknięty katalog władztw, ale z analizy wypowiedzi doktrynalnych można przyjąć zgodność co do władztwa terytorialnego, zadaniowego, finansowego, majątkowego, administracyjnego, organizacyjnego i personalnego ${ }^{15}$. Co więcej, nie istnieje też ustalona relacja między tak wyróżnionymi rodzajami władztwa, ale swoista logika postrzegania gminy jako takiej podpowiada, że najpierw władztwo terytorialne, gdyż bez terytorium nie istnieje żadna jednostka samorządu terytorialnego. Następnie władztwo zadaniowe, wyjaśnia bowiem potrzebę istnienia danej jednostki (jest utworzona do wykonywania zadań publicznych); w dalszej kolejności dwa typy władztwa, które umożliwiają ich wykonywanie finansowe (trzeba mieć możliwość sfinansowania ich wykonania) i majactkowe (trzeba władać materialnym zasobami - nieruchomościami i ruchomościami pozwalającymi samodzielnie wykonywać zadania); władztwo administracyjne, które wyznacza formy wykonywania zadań; władztwo organizacyjne, które pozwala ustrukturalizować jednostkę samorządu terytorialnego wewnętrznie, aby była zdolna wykonywać swoje zadania, i wreszcie personalne, które sym-

13 Jak tłumaczył to Szymański (1849: 383-384): „Gminę franzuzką można uważać jako osobę moralną i jako stowarzyszenie. Jako osoba moralna, ma ona prawo do własności. [...] Uważana jako stowarzyszenie, gmina francuzka ma wszystkie warunki potrzebne do życia społecznego. Ma swą cyrkonskrypcya, czyli granice. Ma swe przychody i wydatki, ma swe władze i organa ze ściśle oznaczonymi atrybucyami, ma stosunki zewnętrzne ze stowarzyszeniami tejże samej natury, wreszcie ma swą odpowiedzialność na wewnątrz i na zewnątrz" (pisownia jak w oryginale). Zob. też Bigo (1928): 171, gdzie wyjaśnia on prywatnoprawny charakter gminy jako stowarzyszenia i różnicę w jej charakterze po reformach początku XIX w., gdy stałą się terytorialną korporacja publicznoprawną.

14 Miemiec (2007): 89.

15 Szersze wyjaśnienia Korczak (2012): 214-239. 
boliczną klamrą zamyka ten katalog (terytorium i mieszkańcy tworza jednostkę samorządu terytorialnego), a zarazem ustala, kto wykonuje jej zadania.

Władztwo terytorialne należy interpretować w dwóch sferach, w każdej $\mathrm{z}$ nich bowiem inną spełnia funkcję i realizuje inne cele, a także inna jest treść tego władztwa. W sferze imperium warunkuje sprawowanie każdego z pozostałych rodzajów władztwa na danym terytorium, choć o samym terytorium $\mathrm{w}$ istocie jednostka samorządu nie decyduje. W sferze dominium trzeba zauważyć, że jednostka samorządu terytorialnego jest jedynie właścicielem nieruchomości położonych na jej terytorium, i to nieruchomości stanowiących składnik mienia samorządowego nabyty pierwotnie w drodze komunalizacji mienia na podstawie przepisów prawa, a wtórnie - w wyniku gospodarowania nieruchomościami na zasadach określonych przepisami prawa, w tym w drodze obrotu cywilnoprawnego. Natomiast gmina, powiat czy województwo nie są właścicielami terytorium tych jednostek.

Choć władztwo terytorialne jest usankcjonowane przywołanymi już przepisami art. 16 ust. 1 Konstytucji oraz art. 1 ustaw: o samorządzie gminnym, o samorządzie powiatowym i o samorządzie województwa, to trzeba jednak podkreślić, że jednostka samorządu terytorialnego nie posiada rzeczywistego i pełnego władztwa terytorialnego, nie może bowiem sama siebie utworzyć, nie może wyznaczyć swoich granic ani ustalić swojej nazwy czy siedziby swoich władz. Pierwotne powstanie gmin, powiatów i województw następowało na mocy ustaw podejmowanych przez Sejm.

W przypadku gmin decydował o tym przepis art. 3 ust. 1 Przepisów wprowadzających z 1990 r. ${ }^{16}$, który stanowił: „Jednostki podziału terytorialnego państwa stopnia podstawowego (miasta, gminy), istniejace w dniu wejścia w życie ustawy, a także miasto stołeczne Warszawa, miasto Kraków i miasto Łódź, zachowują dotychczasową nazwę, obszar, granice i siedzibę władz”. Późniejsze tworzenie nowych gmin następowało już w drodze rozporządzenia Rady Ministrów wydawanego na podstawie art. 4 ust. 1 pkt 1 ustawy o samorządzie gminnym ${ }^{17}$. W przypadku województw ich utworzenie przesądził art. 2 ust. 1 ustawy o wprowadzeniu zasadniczego trójstopniowego podziału terytorialnego państwa, ustalając ich liczbę i nazwy, a art. 3 także siedziby ich władz. Co ciekawe, brak takiej regulacji rangi ustawowej odnośnie do utworzenia powiatów poza dosyć jednak ogólnym przepisem o rodzajach jednostek zasadniczego trójstopniowego podziału terytorialnego państwa z art. 1 ust. 2 tej ustawy: „Jednostkami zasadniczego trójstopniowego podziału terytorialnego państwa są: gminy, powiaty i województwa” oraz delegacją rozporządzeniowa $z$ art. 3 ust. 1 ustawy o samorządzie powiatowym, na podstawie której utworzono 308 powiatów z dniem 1 stycznia 1999 r. ${ }^{18}$,

${ }^{16}$ Ustawa z 10 maja 1990 r. - Przepisy wprowadzające ustawę o samorządzie terytorialnym i ustawę o pracownikach samorządowych (Dz. U. Nr 32, poz. 191 ze zm.).

$17 \mathrm{Z}$ wyjątkiem utworzenia gminy miasto stołeczne Warszawa na mocy ustawy z 15 marca 2002 r. o ustroju miasta stołecznego Warszawy (Dz. U. 2018, poz. 1817).

18 Rozporządzenie Rady Ministrów z 7 sierpnia 1998 r. w sprawie utworzenia powiatów (Dz. U. Nr 103, poz. 652). 
w następnych latach liczba ta wzrosła nawet do 315 powiatów ${ }^{19}$, po czym zmalała do obecnej liczby $314^{20}$.

Żadna z jednostek nie ustala swoich granic ani nie ma wpływu na ich ustalenie. Granice województw w dniu 1 stycznia 1999 r. ustalone zostały przez wykaz gmin wchodzących w ich skład stanowiący załącznik ustawy, a tym samym granice zewnętrzne gmin sassiadujących z gminami należącymi do innego województwa tworzyły sumarycznie granicę województwa, natomiast normatywnie nie został ustalony bezpośrednio przebieg tych granic ${ }^{21}$, ich zmiany zaś odbywają się w drodze rozporządzeń w sprawie tworzenia, łączenia, dzielenie lub znoszenia powiatów zgodnie z art. 5a ustawy o wprowadzeniu zasadniczego trójstopniowego podziały terytorialnego państwa. Przepis co prawda nie wymienia rozporządzenia w sprawie zmiany granic powiatów, podczas gdy obie zmiany, które dotąd nastapiły, wynikały ze zmiany granic powiatów polegajacych na wyłączeniu gmin z powiatów należących do województwa i włączeniu ich do powiatów należących do innego województwa ${ }^{22}$, natomiast nie nastapiła jak dotąd zmiana granic województwa związana z literalną treścia tego przepisu, choć oba rozporządzenia powoływały się na ów przepis. Granice gmin ustala Rada Ministrów w drodze rozporządzenia wydanego na podstawie delegacji rozporządzeniowej z art. 4 ust. 1 pkt 1 ustawy o samorządzie gminnym, a granice powiatów z art. 3 ustawy o samorządzie powiatowym ${ }^{23}$.

Gminy utworzone w 1990 r. przejęły nazwy gmin dotychczasowych, zgodnie z przywołanym już przepisem art. 3 ust. 1 Przepisów wprowadzajacych, i tym samym nie mogły mieć nawet wpływu na jej ustalenie, co też wykluczył przepis art. 4 ust. 1 pkt 3 ustawy o samorządzie gminnym, przyznając tę kompetencję wyłącznie Radzie Ministrów ${ }^{24}$. Powiatom utworzonym w 1998 r. nadano nazwy we wspomnianym rozporządzeniu i w następnych pięciu rozporządzeniach dokonywano ich zmian, przy czym należy też pamiętać o pięciu rozporządzeniach tworzących nowe powiaty, którym za każdym razem nadawano nazwy.

Siedziby władz gmin w 1990 r., zgodnie z przywołanym przepisem art. 3 ust. 1 Przepisów wprowadzających, pozostawały niezmienione w stosunku do siedzib rad narodowych gmin dotychczasowych, tworzone w późniejszym czasie nowe gminy miały ustalane siedziby w odpowiednich rozporządzeniach,

19 Na mocy rozporządzenia Rady Ministrów z 31 maja 2001 r. w sprawie utworzenia, ustalenia granic i zmiany nazw powiatów oraz zmiany siedziby władz powiatów (Dz. U. Nr 62, poz. 631).

${ }^{20} \mathrm{Na}$ mocy art. 16 ust. 1 ustawy o ustroju miasta stołecznego Warszawy zniesiono powiat warszawski.

21 Pominąc można granice województw stanowiące zarazem granicę państwową której przebieg wyznaczony jest umowami międzynarodowymi zgodnie z art. 2 ustawy z 12 października 1990 r. o ochronie granicy państwowej (Dz. U. 2019, poz. 1776).

22 Rozporządzenia Rady Ministrów: z 31 maja 2001 r. w sprawie zmiany granic województwa małopolskiego i śląskiego (Dz. U. Nr 62, poz. 630) i z 25 czerwca 2002 r. w sprawie zmiany granic województwa podkarpackiego i małopolskiego (Dz. U. Nr 93, poz. 823).

${ }^{23} \mathrm{Z}$ jednym wyjątkiem, kiedy zmieniono granice powiatu mińskiego, włączając do niego gminę Sulejówek na mocy art. 16 ust. 1 ustawy o ustroju miasta stołecznego Warszawy.

24 Jak dotąd wydano łącznie 29 rozporządzeń, których przedmiotem była zmiana nazwy gminy (z tego 13 polegało na zmianach pozostałych 16 rozporządzeń). 
ale tė̇ w 28 rozporządzeniach dokonywano zmian tych siedzib. Podobnie przedstawia się sytuacja wyznaczenia siedzib władz powiatów ustalonych w rozporządzeniu z 1998 r. i każdorazowym wydanym później z racji tworzenia nowych powiatów, ale też w trzech rozporządzeniach zmieniano siedziby istniejących powiatów.

Na czym zatem w istocie polega władztwo terytorialne gmin, skoro nie odnosi się do samego terytorium jako takiego? Otóż - jak wspomniano - władztwo terytorialne warunkuje korzystanie z pozostałych rodzajów władztwa. Dzięki władztwu terytorialnemu w ramach władztwa zadaniowego gmina zyskuje wyłączność wykonywania zadań na swoim terytorium, jeśli gmina nie skorzysta z form współdziałania gminnego - nie powierzy innej gminie w drodze porozumienia międzygminnego wykonywania określonych nim swoich zadań na swoim terytorium przez jej jednostki organizacyjne lub nie przystapi do związku gminnego lub powiatowo-gminnego, który na jej terytorium będzie wykonywał jej zadania w ramach swojej statutowej działalności - względnie nie powierzy wykonania zadania w ramach umowy partnerstwa publiczno-prywatnego, względnie zleci, na zasadach określonych ustawą o działalności pożytku publicznego i o wolontariacie, to żaden podmiot nie może wkroczyć w jej władztwo zadaniowe.

W ramach władztwa administracyjnego, dzięki władztwu terytorialnemu, wyłącznie jej organy stanowiące mogą na podstawie upoważnień ustawowych stanowić akty prawa miejscowego, którymi władczo mogą ingerować w sferę praw i wolności zarówno swoich mieszkańców, jak i każdego, kto znajdzie się na jej terytorium ${ }^{25}$, ale też mogą zrealizować dążenie mieszkańców do zachowania ich przynależności etnicznej i narodowej, gdy przy spełnieniu odpowiednich warunków można na ternie gminy używać języka mniejszości narodowych czy regionalnego jako języka pomocniczego, a także wprowadzać podwójne nazewnictwo zarówno samych miejscowości, jak i ulic, placów, obiektów fizjograficznych i obiektów użyteczności publicznej ${ }^{26}$. Szczególnie jest to odczuwalne w ramach władztwa planistycznego gminy realizowanego przez miejscowe plany zagospodarowania przestrzennego, które ingerują w prawo własności nieruchomości, gdy chodzi o sposób jej zagospodarowania ${ }^{27}$. W ramach władztwa finansowego, dzięki władztwu terytorialnemu i władztwu administracyjnemu, organy stanowiące gmin mogą w drodze aktów prawa miejscowego ustalać stawki podatków lokalnych, a także ustanawiać niektóre opłaty lokalne i ich stawki, ale też mają możliwość wydatkowania przewidzianych w budżecie środków na sfinansowanie wykonania zadań, w tym także udzielania pomocy

25 Najlepszą ilustrację stanowi uchwała w sprawie ustalenia strefy płatnego parkowania lub śródmiejskiej strefy płatnego parkowania czy opłatę dla obiektów mostowych lub tuneli i przepraw promowych z art. 13-13e ustawy z 21 marca 1985 r. o drogach publicznych (Dz. U. 2020, poz. 470).

${ }^{26}$ Chodzi o szczególny status gminy zamieszkanej przez mniejszość narodową lub etniczną w rozumieniu przepisów ustawy z 6 stycznia 2005 r. o mniejszościach narodowych i etnicznych oraz o języku regionalnym (Dz. U. 2017, poz. 823).

${ }_{27}$ Zob. art. 6 i art. 37a-37d ustawy z 27 marca 2003 r. o planowaniu i zagospodarowaniu przestrzennym (Dz. U. 2020, poz. 293). 
finansowej swoim mieszkańcom ${ }^{28}$. W ramach władztwa organizacyjnego, dzięki władztwu terytorialnemu i administracyjnemu, organy stanowiące gminy moga określić ustrój gminy w drodze jej statutu, ale też mogą zorganizować wspólna obsługę z art. 10a ustawy o samorządzie gminnym, tworzyć gminne jednostki organizacyjne i gminne osoby prawne przewidziane przepisami prawa. Wreszcie władztwo personalne pozwala mieszkańcom gminy dokonać wyboru swoich przedstawicieli do organu stanowiącego i osoby piastujaccej urząd organu wykonawczego gminy, a wójtowi (burmistrzowi i prezydentowi) zatrudniać kierowników gminnych jednostek organizacyjnych i pracowników urzędu.

\section{REALNY WYMIAR WŁADZTWA TERYTORIALNEGO W ŚWIETLE REGULACJI USTAWOWYCH I ROZPORZĄDZENIOWYCH ORAZ ROZSTRZYGNIĘĆ NADZORCZYCH I ORZECZNICTWA SĄDOWEGO}

Powyższa analiza nadaje władztwu terytorialnemu bardziej realnego wymiaru. Jest to władztwo sprawowane przez organy władzy publicznej na podstawie i w granicach prawa zgodnie z art. 7 Konstytucji RP. Jego zakres nie jest tak szeroki, jak tego można było oczekiwać po deklaracjach z 1990 r. Jeśli jednak gmina i jej organy nie stały się w pełni samodzielnymi gospodarzami swoich terytoriów, to na pewno nie służy władztwo terytorialne do realizacji celów z nim niezgodnych, gdy powołując się na nie, organy gminy zaczynają różnicować status osób przebywających na terenie gminy, najpierw na „swoich”, czyli mieszkańców, i „obcych”, czyli pochodzących z innych gmin ${ }^{29}$, a ostatnimi czasy na mieszkańców wyznających zwyczajowo przyjęte systemy wartości w sferze życia prywatnego i takich, którzy ich nie wyznają ${ }^{30}$. Przypomnieć za-

28 Są to świadczenia pieniężne w ramach świadczeń z zakresu pomocy społecznej na mocy przepisów ustawy z 12 marca 2004 r. o pomocy społecznej (Dz. U. 2019, poz. 1507), ale też pomoc materialna dla uczniów z rozdziału 8a ustawy z 7 września 1991 r. o systemie oświaty (Dz. U. 2020, poz. 1327), czy różnego rodzaju stypendia dla uczniów i studentów.

${ }_{29}$ Rady gmin miały skłonność do różnicowania stawek opłaty targowej dla sprzedających będących mieszkańcami gminy lub przedsiębiorcami mającymi siedzibę na jej terytorium i spoza gminy - zob. np. uchwała Kolegium RIO w Zielonej Górze z 21 grudnia 2011 r. nr 602/2011 (Dz. Urz. Woj. Lubus. 2012, poz. 119).

${ }^{30} \mathrm{~W}$ kilku województwach rozpowszechniła się moda na podejmowanie uchwał w sprawie ustanowienia w gminie strefy wolnej od LGBT, co przy braku reakcji organów nadzoru, a wręcz akceptacji - Wojewoda Lubelski nagrodził takie gminy (<https://www.portalsamorzadowy.pl/polityka-i-spoleczenstwo/wojewoda-nagrodzil-medalami-samorzady-wolne-od-ideologii-lgbt,125925. html> [dostęp: 25.07.2020]) - umacnia radnych i niektórych mieszkańców w przekonaniu o słuszności i dopuszczalności takich działań w świetle prawa, choć żaden przepis prawa nie stanowi podstawy prawnej do podjęcia takiej uchwały (pozbawianie ich cech uchwały przez określanie jako apel, stanowisko itp. jest sprzeczne z art. 14 ust. 1 ustawy o samorządzie gminnym). Wyroki uchylające te uchwały WSA w Gliwicach, III SA/Gl 15/20, z 14 sierpnia 2020 r. (CBOSA) i WSA w Warszawie VIII, SA/Wa 42/20, z 15 lipca 2020 r. (CBOSA) spotkały się z bezprzykładnymi reak- 
tem wypada, że członkostwo we wspólnocie, mając charakter przymusowy, nie pozwala nikogo wykluczać ze wspólnoty ani też pozbawiać członka wspólnoty przynależnej mu godności ludzkiej i tym samym nie może uchwała rady gminy nikogo oceniać za jego zachowania, skoro nawet gdy narusza nim normy prawa, to podlega ocenie właściwych organów, ale nie samorządowych ${ }^{31}$.

Pomijając zjawiska patologiczne, należy zwrócić uwagę, że zakres dopuszczalnego prawem władztwa terytorialnego doznaje jednak istotnych ograniczeń w toku korzystania z poszczególnych atrybutów władztwa w wyniku podejmowanych działań legislacyjnych oraz polityki nadzorczej. Podjęte poniżej wątki są jedynie przykładowymi i nie wyczerpują spektrum tych ograniczeń.

\section{Zmiany w podziale terytorialnym i udział wspólnoty samorządowej w jego przeprowadzaniu}

Jak wspomniano, wprowadzając trójstopniowy podział terytorialny, ustawodawca zastrzegł dokonywania podziału państwa na województwa wyłącznie dla Sejmu i formy ustawowej, natomiast tworzenie i znoszenie oraz zmiany w postaci dzielenia i łączenia bądź też zmiany granic w przypadku powiatów i gmin pozostawiono w gestii Rady Ministrów oraz formy rozporządzenia. Tym samym przyjmował racjonalne zresztą założenie, że podział nie będzie niezmienny i w miarę tego, jak będą ujawniały się słabości mapy administracyjnej, popełnione błędy przy ustalaniu zarówno liczby jednostek, jak i ich granic, czy też zaistnieją inne przesłanki, dokonywane będą korekty ${ }^{32}$. Zmienność podziału może przyjmować bardzo różny zakres: od korekt granic, przez dzielenie i łączenie jednostek, aż po całkowitą zmianę podziału, co miało miejsce niemal od samego początku istnienia współczesnego samorządu ${ }^{33}$, ze szczególnym nasileniem w Niemczech w latach 1968-1978, kiedy w wyniku

cjami Prokuratury Krajowej i wiceministra sprawiedliwości, zapowiadającymi skargi kasacyjne z uwagi na ograniczenie prawa wspólnoty samorządowej do wyrażenia swoich poglądów.

${ }^{31} \mathrm{~W}$ okresie międzywojennym, kiedy narastał w Polsce antysemityzm, w Puszczykówku nad Wartą (k. Poznania) wydzielono plażę dla chrześcijan z zakazem wstępu dla żydów, nie było to co prawda wynikiem działania ówczesnych władz samorządowych, ale też nie spotkało się z żadna ich reakcja (<http://poznan.jewish.org.pl/index.php/antysemityzm./Plaza-w-Puszczykowku-bez-Zydow.html> [dostęp: 20.06.2020]. Z kolei Lipowicz (2019: 192-193) opisuje absolutnie odmienne zachowania w ramach władztwa terytorialnego, gdy gminy niektórych państw dopuszczają do czynnego udziału w działaniach ich organów zamieszkujących na ich terenie migrantów niemających obywatelstwa danego państwa. Zatem odmienność kulturowa, etniczna i narodowa nie musi skłaniać do stygmatyzacji i marginalizacji.

${ }^{32}$ Pomijając już to, że tworzenie mapy województw odbywało się w atmosferze nieustannych sporów i nacisków społecznych (przykład Opolszczyzny) oraz politycznych (przykład województwa świętokrzyskiego) i z początkowych zamierzeń 12 dużych województw (Wysocka, Koziński 1993: 3-88) skończyło się na 16, to także tworzenie mapy powiatów nie było wolne od niekonsekwencji, co niemal po wejściu w życie ustaw i rozporządzeń wykonawczych reformy z 1998 r. skłaniało do wielu krytycznych ocen i wniosków o korektę - Szot (2000); Korczak (2000): 113-114.

${ }^{33}$ Hamann (2005: 5) przywołuje pierwsze reformy terytorialne gmin w Królestwie Bawarii z 1808 r.: Edikt über die Bildung der Gemeinden vom 28. Juli 1808 (RBl. 1808, Sp. 2789) oraz Edikt über das Gemeindewesen vom 24. September 1808 (RBl. 1808 Sp. 2405), które z 40 tys. gmin, sołectw i przysiółków utworzyły 7 tys. nowych gmin. 
konsolidacji zredukowano liczbę gmin o 2/3, a po zjednoczeniu w nowych krajach związkowych w latach 1992-1994 nastapiły konsolidacje gmin i powiatów, reformy zaś nadal nie ustają ${ }^{34}$, podobnie jak w krajach skandynawskich, Austrii, Grecji czy w Zjednoczonym Królestwie. Gdy jednak proces zmian trwa nieprzerwanie w Szwajcarii, to w sassiedniej Francji liczba gmin od 1789 r. nie uległa zmianie ${ }^{35}$.

Zmiany nie zawsze sa przyjmowane ze zrozumieniem $^{36}$ i akceptacja, jak jednak podkreśla się w doktrynie, są one nieuniknione i wprost konieczne. Mimo to, jak słusznie zauważa Lipowicz: „Rola mieszkańców gminy w podejmowaniu tak doniosłego rozstrzygnięcia, jak utworzenie nowej gminy, jej likwidacja [...] jest relatywnie niewielka [...]"37, a stwierdzić wypada, że wielokrotnie wręcz ignorowana przez organy uprawnione do dokonania zmian. Przypomnieć należy, że ustawa przewiduje trzy procedury inicjowania zmian w podziale terytorialnym na poziomie gminy: $\mathrm{z}$ inicjatywy samej Rady Ministrów (art. 4a), gdzie wymagane sąjedynie opinie rad gmin wyrażone w formie uchwał podjętych po konsultacjach z mieszkańcami; z inicjatywy rady gminy podjętej po konsultacjach $\mathrm{z}$ mieszkańcami i opiniowanej przez rady gmin objęte wnioskiem również wymagające konsultacji (art. 4b) i z inicjatywy samych mieszkańców wyrażonej w drodze referendum gminnego (art. 4c). W praktyce przypadek z art. 4c miał zastosowanie tylko jeden raz i skutkował jedynym w Polsce dobrowolnym połaczeniem gmin miasta na prawach powiatu Zielona Góra i gminy Zielona Góra ${ }^{38}$, najczęściej zatem rozporządzenia są inicjowane w trybie art. 4a i 4b, przy czym inicjowanie przez gminy zmierza ku powiększeniu swojego terytorium kosztem gmin graniczących z nią.

Konfliktogenność modelu zmian przyjętego w ustawie o samorządzie gminnym opiera się na błędnym założeniu - gmina większa (z reguły o statusie miasta) ma prawo rozwijać się kosztem gminy mniejszej (z reguły tzw. gminy wiejskiej) - podczas gdy nie istnieją żadne racjonalne tego przesłanki ${ }^{39}$.

${ }^{34}$ O reformie terytorialnej w Niemczech zob. Korczak (199): 265-266.

${ }^{35}$ Przegląd sytuacji w krajach europejskich zob. Korczak (2014): 60-65.

${ }^{36} \mathrm{Na}$ reformy w Niemczech reagowali negatywnie nawet przedstawiciele doktryny prawa samorządowego np. Seidel (1978: 14) skwitował je następującymi słowami „Schematismus, Zahldenken, Großenwahn, Reißbrettstrategie, Bürgervormordung, Tod der Selbstverwaltung”. Konsolidacja z 2010 r. w Meklemburgii - Pomorzu Przednim doprowadziła do rozpadu rządzącej koalicji, z powodu oporu społeczeństwa rząd Turyngii wycofał się z planowanego na 2020 r. „Dreistadt” Erfurt-Weimar-Jena.

${ }^{37}$ Lipowicz (2019): 279.

${ }^{38}$ Rozporządzenie Rady Ministrów z 29 lipca 2014 r. w sprawie połączenia gmin, ustalenia granic niektórych gmin i miast, nadania niektórym miejscowościom statusu miasta oraz zmiany siedziby władz gminy (Dz. U. 2014, poz. 1023).

${ }^{39}$ Rzeszów w latach 2006-2017 powiększył swoją powierzchnię dwukrotnie i doprowadziły do wzrostu liczby mieszkańców o 80\%. Znany jest powszechnie konflikt dwóch stowarzyszeń samorządowych: Związku Miast Polskich, który lobbuje za kolejnymi zmianami granic miast kosztem graniczących z nimi gmin wiejskich, i Związku Gmin Wiejskich, który uważa, że jedyną drogą do poprawy jakości świadczonych usług i wzrostu gospodarczego wszystkich sąsiadujacych ze sobą gmin jest realizowana w różnych wymiarach współpraca i porozumienie. Co więcej, prognozy demograficzne wskazują, że większość obecnych dużych miast czeka depopulacja rzędu kilku do kilkunastu procent, co nie uzasadnia ich rozrostu terytorialnego. 
Okres cywilizacji, w którym zamieszkanie w mieście było swoistym awansem, zdecydowanie odszedł do przeszłości, skoro współcześnie mieszkańcy miast coraz częściej i chętniej przeprowadzają się do miejscowości niebędących miastami nie tylko z prawnego, ale też urbanistycznego punktu widzenia. Również okres, w którym rozbudowa miast odbywała się bez strat innych miejscowości, ponieważ zajmowano tereny niezamieszkałe i z reguły niezagospodarowane, należy do przeszłości. Suburbizacja, urban sprawl to procesy, które powoduja, że każda próba wyjścia z zabudową poza granice administracyjne gminy oznacza wejście nie tylko na teren innej jednostki podziału terytorialnego, ale z reguły w przestrzeń już zagospodarowana - tak jak w przypadku Opola, które w 2016 r. powiększyło swoją powierzchnię o 55\%.

Przypadek Opola wart jest uwagi, ponieważ rozporządzenie zostało wydane na jego wniosek w atmosferze bardzo intensywnych i dramatycznych wręcz oporów ze strony gmin tracących zagospodarowane miejscowości o dużej wartości zainwestowania (od 20 do $69 \mathrm{mln}$ zł) i liczbie mieszkańców (nawet do 30\%). Jednakże nie tylko kwestia utraconej powierzchni, majątku i liczby mieszkańców miały tu znaczenie. Każda z tych gmin posiadała status zamieszkanej przez mniejszość narodową i mieszkańcy miejscowości objętych rozporządzeniem w sprawie zmiany granic po włączeniu do Opola, które takie statusu nie posiada, utracili swoje prawa podmiotowe do używania języka pomocniczego oraz stosowania w tych miejscowościach podwójnego nazewnictwa. Wszystkie te argumenty zostały zupełnie zignorowane, i to w sposób odbiegający od wszelkich reguł, jakich należałoby oczekiwać po członku Rady Europy, który ratyfikował EKSL czy Konwencję o ochronie praw mniejszości ${ }^{40}$.

W doktrynie problem konfliktowości tego modelu jest rozpatrywany w kilku płaszczyznach, m.in. kwalifikacji normatywnej rozporządzenia w sprawie zmian w podziale terytorialnym oraz wynikajaccych z niej konsekwencji w zakresie kontroli sądowej rozporządzenia oraz środków prawnych przysługujących gminie, która uznaje, że jej prawa są naruszone. Orzecznictwo Trybunału Konstytucyjnego jest w tej mierze jednak dalece niesatysfakcjonujace dla zainteresowanych, uznał on bowiem, że rozporządzenie nie nosi cech normatywności i jako takie nie podlega badaniu zgodności z Konstytucja, ustawami i ratyfikowanymi umowami międzynarodowymi, co skłania przedstawicieli doktryny do oceny krytycznej uznania rozporządzenia za indywidualny akt normatywny ${ }^{41}$.

Niemniej kontrowersyjne jest likwidowanie gmin ${ }^{42}$, choć $\mathrm{w}$ wielu analizach wskazuje się, że liczba gmin w Polsce jest za duża, a przy tym wiele z nich dysponuje zbyt małym potencjałem mienia i finansów, aby zaspokajać zbio-

${ }^{40}$ Analiza treści oceny przepisów rozporządzenia Szmulik (2017: 149-165) prowadzi do bardzo niepokojących konkluzji co do jej obiektywności i zachowania proporcji między wartościami reprezentowanymi przez interes jednej gminy, a wartościami, które winno chronić prawo.

41 Dolnicki (2017): 56-64; podobnie Mączyński (2020): 153-165; Feja-Paszkiewicz (2010): 26-28, Bujny, Kudra (2015): 95-104.

42 Pomijam przypadek warszawski, gdzie w 2002 r., zmieniając ustrój Warszawy, zlikwidowano 7 gmin-dzielnic warszawskich (podobnie jak to działo się we wspomnianym 1990 r., gdy likwidowano gminy-dzielnice województw miejskich). 
rowe potrzeby swoich mieszkańców efektywnie, co skłania do wnioskowania o zmniejszenie tej liczby ${ }^{43}$, choćby przez ich łączenie. Jednak czym innym jest dobrowolne łączenie, jak w zielonogórskim kazusie, czym innym zaś likwidacja gminy Ostrowice dokonana w wyniku wcześniejszego zaniechania ze strony organów nadzoru - tu Regionalnej Izby Obrachunkowej w Szczecinie działań zapobiegających zadłużeniu gminy do sytuacji niepozwalającej jej samodzielnie realizować zobowiązania. Przypadek ten przeczy dotychczasowym poglądom doktrynalnym o odrębności terytorialnej korporacji publicznoprawnej od innych osób prawnych brakiem upadłości i likwidacji z tego powodu. Kuriozalność tego przypadku polega też na tym, że rozporządzenie w sprawie zniesienia gminy ${ }^{44}$ zostało wydane nie na podstawie art. 4 ust. 1 ustawy o samorządzie gminnym, ale na mocy specjalnej ustawy ${ }^{45}$, co może zachęcać do podobnych działań w przyszłości ${ }^{46}$.

\section{Ustalanie nazewnictwa ulic, placów i obiektów publicznych}

W doktrynie w odniesieniu do gminy często zwraca się uwagę na przejaw władztwa terytorialnego i administracyjnego zarazem, polegajacego na nadawaniu nazw ulic i placów będących drogami publicznymi na podstawie upoważnienia z art. 18 ust. 2 pkt 13 ustawy o samorządzie gminnym. Pomijając dawne spory o charakter prawny takiej uchwały, który ostatecznie zakwalifikowano słusznie do kategorii aktów prawa miejscowego z racji tego chociażby, że stosowanie nadanej nazwy obowiązuje nieograniczony krag adresatów, należy zwrócić uwagę na istotną ingerencję w owo władztwo na mocy dosyć kontrowersyjnej ${ }^{47}$ regulacji prawnej o zakazie propagowania komunizmu ${ }^{48}$, m.in. przez nazwy obiektów i urządzeń użyteczności publicznej, do których art. 1 tej ustawy zaliczył też drogi, ulice, mosty i place. Zgodnie z jej art. 2 ust. 1 wojewoda zyskał upoważnienie do stwierdzenia nieważności uchwały nadajacej taka nazwę jedynie na podstawie opinii Instytut Pamięci Narodowej, która w świetle orzecznictwa jest jedynie „niewiążącym poglądem określonego organu dysponującego wiedzą fachową w kwestii zasadności i prawidłowości projektowanych rozwiązań przedłożonych do zaopiniowania”49.

43 Bardzo ciekawe są wyniki analizy problemu wielkości gmin Swianiewicz (1995): 23-34; (2010): 5-16.

${ }_{44}$ Rozporządzenie Rady Ministrów z 7 sierpnia 2018 r. w sprawie zniesienia gminy Ostrowice oraz ustalenia granic gminy Drawsko Pomorskie i gminy Złocieniec (Dz. U. poz. 1527).

45 Ustawa z 5 lipca 2018 r. o szczególnych rozwiązaniach dotyczących gminy Ostrowice w województwie zachodniopomorskim (Dz. U. poz. 1432).

${ }^{46}$ O takich zagrożeniach pisze też Lipowicz (2019): 144-147.

${ }^{47}$ Kontrowersje wzbudza sam termin „komunizm” użyty w odniesieniu do ustroju państwa polskiego lat 1944-1989, co zdaniem komentatorów jest „dalece nieprecyzyjne” wobec niejasności znaczenia tego terminu - zob. Makowska, Makowski (2019).

48 Ustawa z 1 kwietnia 2016 r. o zakazie propagowania komunizmu lub innego ustroju totalitarnego przez nazwy jednostek organizacyjnych, jednostek pomocniczych gminy, budowli, obiektów i urządzeń użyteczności publicznej oraz pomniki (Dz. U. 2018, poz. 1103).

${ }^{49}$ Wyrok NSA z 17 kwietnia 2018 r., II OSK 658/18, CBOSA. 
Co więcej, jeśli w terminie trzech miesięcy od dnia uprawomocnienia się rozstrzygnięcia stwierdzającego nieważność wspomnianej uchwały nie zostanie nadana nowa nazwa, a jest to konieczne w przypadku nazwy ulicy z racji oznaczenia adresu, wojewoda został przepisem art. 3 ustawy upoważniony do wydania zarządzenia zastępczego w sprawie nadania nazwy, co skłania do kolejnych uwag krytycznych co do samej konstrukcji zarządzenia w tej sprawie, a także przesłanek jego wydania ${ }^{50}$. Wreszcie w art. 6 zobowiazano organy stanowiace jednostek samorządu terytorialnego do zmiany nazw, które obowiązywały w dniu wejścia w życie ustawy w terminie do 12 miesięcy (tj. 2 września 2017 r.), a upamiętniały w rozumieniu ustawy „osoby, organizacje, wydarzenia lub daty symbolizujące komunizm lub inny ustrój totalitarny", z jednoczesnym upoważnieniem wojewody do wydania zarządzenia zastępczego zmieniającego takie nazwy. Nadto po kolejnej nowelizacji tej ustawy art. $6 \mathrm{~b}$ zobowiązano gminę do uzyskania zgody IPN na zmianę nazwy ustalonej rozporządzeniem zastępczym, a zarazem ograniczono jej prawo do skargi na zarządzenia zastępcze w art. $6 c^{51}$.

\section{ZAKOŃCZENIE}

Przeprowadzona w artykule analiza regulacji prawnych odnoszacych się do tworzenia, łączenia, dzielenia i likwidacji, a także ustalania granic i siedziby władz gminy jako podstawowej jednostki samorządu terytorialnego dowodzi, że pierwotne wyobrażenia o władztwie terytorialnym gminy okazały się odległe od jego realnej treści. Rozwiązania ustawy z 1990 r. nie stabilizuja w żaden sposób podziału terytorialnego, ale też nie chronią praw wspólnot samorządowych. Ich stosowanie realizuje natomiast cele polityczne zarówno ugrupowań rządzących, jak i wywierających na nie wpływ grup nacisku. Wyraźny jest też konflikt między miastami z otaczajacymi je gminami wiejskimi, przy czym praktyka dowodzi, że w procedurach inicjowania kolejnych rozporządzeń interesy rozrastających się miast dominują nad interesami gmin wiejskich broniących swego status quo.

Słabości tych rozwiązań są wzmacniane przyjętą linią orzeczniczą Trybunału Konstytucyjnego, który nie znajduje jak dotąd uzasadnienie wywiedzenia z Konstytucji argumentacji pozwalającej stwierdzić istnienie prawa podmiotowego gminy, jak też samej wspólnoty samorządowej jej mieszkańców jako wartości dajacej podstawę do przeciwstawienia się kolejnej zmianie granic czy nawet likwidacji gminy. Odmawia się prawa gminie jako osobie prawnej, ale też każdej z osób zamieszkałych na jej terytorium do stanowienia o sprawie o najbardziej fundamentalnym dla nich znaczeniu - o tożsamości terytorialnej, o poczuciu przynależności do wspólnoty w jej aspekcie osobowym,

50 Szlachetko (2019): 51-53.

${ }^{51}$ O kontrowersyjności tego przepisu świadczą wyroki sądów administracyjnych, jedynie dla przykładu przywołać można wyrok WSA w Poznaniu, IV SA/Po 798/18, z 24 stycznia 2019 r. i wyrok NSA, II OSK 3260/18, z 20 marca 2019 r. (CBOSA). 
a także przestrzennym. Mieszkańcy gminy wiejskiej przyłączeni do miasta socjologicznie i kulturowo mogą co najwyżej poczuć się swoistymi samorządowymi apatrydami, ale we współczesnych warunkach cywilizacyjnych nie zyskuja poczucia awansu.

Władztwo terytorialne doznaje też istotnych ograniczeń, gdy ideologiczne poglądy dominują proces legislacyjny do tego stopnia, że dla ich realizacji narzuca się mieszkańcom gmin nakazy i zakazy w sferze ich spraw o wyjątkowo lokalnym charakterze - nazw ulic i placów, przy których mieszkaja, często przez całe swoje życie, nie bacząc na ich przyzwyczajenia czy inne wartości, które winny znaleźć poszanowanie.

Jerzy Korczak

Uniwersytet Wroctawski

jerzy.korczak@uwr.edu.pl

https://orcid.org/0000-0003-1104-4837

Augustyniak, M. (2010). Jednostki pomocnicze gminy. Warszawa.

Bethelémy, H. (1920). Traité elémenetaire de droit adminsitratif. 9 edition. Paris.

Bigo, T. (1928). Związki publiczno-prawne w świetle ustawodawstwa polskiego. Warszawa.

Blieback, K.-J. (1976). Die öffentliche Körperschaft. Ihre Entstehtung, die Etwcklung ihres Begrife und das Lehre vom Staat und den innerstaatlichen Verbänden in der Epoche des Konstitutionalismus in Deutschland. Schriften zum Öffentlichen Recht 286: 375-451.

Boć, J. (red.) (2010). Prawo administracyjne. Wrocław.

Bujny, J., Kudra A. (2015). Połączenie gmin - problemy pojęciowe. Samorząd Terytorialny 25(7): 95-104.

Dolnicki, B. (2017). Indywidualny akt normatywny. Przegląd Prawa Publicznego 6: 56-64.

Feja-Paszkiewicz, A. (2010). Ustalenie i zmiana granic gmin w orzecznictwie Trybunału Konstytucyjnego - wybrane problemy. AUW. Przegląd Prawa i Administracji 82: 26-28.

Fleiner, F. (1922). Institutionen des deutschen Verwaltungsrecht. Tübingen.

Hamann, P. (2005). Gemeindegebietsreform in Bayern. Entwicklungsgeschichte, Bilanz und Perspektiven. München.

Jellinek, G. (1920). Allgemeine Staatslehre. Berlin.

Kirste, S. (2017). Theorie der Körperchaft des öffentlichen Rechts. Verwaltungshistorische, organisationstheoretische und verwaltungsorgasnisationrechtliche Aspekte. Heidelberg.

Korczak, J. (1999). W Niemczech, [w:] J. Jeżewski (red.), Samorząd terytorialny i administracja w wybranych krajach. Gmina w państwach Europy Zachodniej. Wrocław: 265-266.

Korczak, J. (2000). Wdrażanie reformy administracji publicznej - próba oceny, [w:] S. Dolata (red.), Prawne i finansowe aspekty funkcjonowania samorządu terytorialnego. Tom 1: Prawo samorządowe i administracyjne. Opole: 113-114.

Korczak, J. (2012). Konstytucyjne podstawy struktury i funkcji samorządu terytorialnego, [w:] R. Hauser, Z. Niewiadomski, A. Wróbel (red.), System prawa administracyjnego. Tom 2: Konstytucyjne podstawy funkcjonowania administracji publicznej. Warszawa: 190, 212-239.

Korczak, J. (2014). W sprawie reform konsolidacyjnych w polskim samorządzie terytorialnym, [w:] J. Sługocki (red.), Dziesięć lat polskich doświadczeń w Unii Europejskiej. Problemy prawnoadministracyjne. Tom 2. Wrocław: 48, 60-65.

Lipowicz, I. (2019). Samorzą terytorialny XXI wieku. Warszawa.

Lisowski, P. (2013). Relacje strukturalne w polskim samorządzie terytorialnym. Wrocław.

Makowska, M., Makowski, M. (2019). Zakaz propagowania komunizmu lub innego ustroju totalitarnego przez nazwy jednostek organizacyjnych, jednostek pomocniczych gminy, budowli, obiektów i urządzeń użyteczności publicznej oraz pomniki. Komentarz. Wydanie 2. Lex/el.

Mączyński, M. (2020). Glosa do postanowienia Trybunału Konstytucyjnego z dnia 12 czerwca 2019 r., U 1/19. Gdańskie Studia Prawnicze 24(1): 153-165. 
Miemiec, M. (2007). Gmina w systemie administracji publicznej Republiki Federalnej Niemiec. Wrocław.

Niewiadomski, Z. (red.) (2002). Prawo administracyjne. Część ustrojowa. Warszawa.

Seidel, A. (1978). Abschluß der kommunalen Gebietsreform in Bayern. Der Bayerische Bürgermeister 4(29): 11.

Swianiewicz, P. (1995). Czy małe jest piękne? Czy duże jest efektywne? Wielkość gmin w teorii i praktyce. Samorzą Terytorialny 5(7/8): 23-34.

Swianiewicz, P. (2009). Czy rozmiar ma znaczenie? Zróżnicowanie opinii mieszkańców o funkcjonowaniu samorządów lokalnych w zależności od wielości gminy. Samorząd Terytorialny 19(4): 5-16.

Szlachetko, K. (2019). Instrumentalizacja nadzoru nad samorządem terytorialnym na przykładzie regulacji zarządzenia zastępczego wojewody $\mathrm{w}$ sprawach związanych $\mathrm{z}$ dekomunizacja przestrzeni publicznej. Samorząd Terytorialny 6: 48-80.

Szmulik, B. (2017). Oceny przepisów rozporządzenia Rady Ministrów w sprawie ustalenia granic niektórych gmin i miasta, nadania niektórym miejscowościom statusu miasta oraz zmiany nazwy gminy w kontekście zmiany granic miasta Opola w świetle przepisów konstytucyjnych, ustawy o mniejszościach narodowych i etnicznych oraz o języku regionalnym, prawa międzynarodowego, w tym konwencji ramowej o ochronie mniejszości narodowych. Przegląd Sejmowy 2(139): 149-165.

Szot, E. (2000). Potrzebne korekty na mapie. Rzeczpospolita (18)36.

Szymański, A. (1849). O administracyi francuzkiéj. Przegląd Poznański. Pismo miesięczne 9: 386. Ura, E. (2010). Prawo administracyjne. Warszawa.

Winczorek, P. (2000). Komentarz do Konstytucji RP z 2 kwietnia 1997 r. Warszawa.

\section{THE TERRITORIAL AUTHORITY OF THE MUNICIPALITY: FROM IDEAS TO MYTH}

\section{Summary}

The article is devoted to the essence of the municipality, which is a community formed from the inhabitants of a territorial division unit, which should manifest itself in the exercise of power in that territory. The article focuses on one of the key manifestations of municipal government as the foundation of its independence. The analysis of the laws, together with their judicial and doctrinal interpretation, will answer the question of whether the idea of territorial authority has any basis in truth, or whether it is merely mythical idea.

Keywords: municipality; territory of the municipality; municipal name; municipal headquarters; municipal boundaries; territorial authorities 
